\title{
DNA-templated Fabrication of 1D-Parallel and 2D-Crossed Metallic Nanowire Arrays
}

Zhaoxiang Deng, Chengde Mao*

Department of Chemistry, Purdue University, West Lafayette, Indiana 47907

\section{Supporting information}

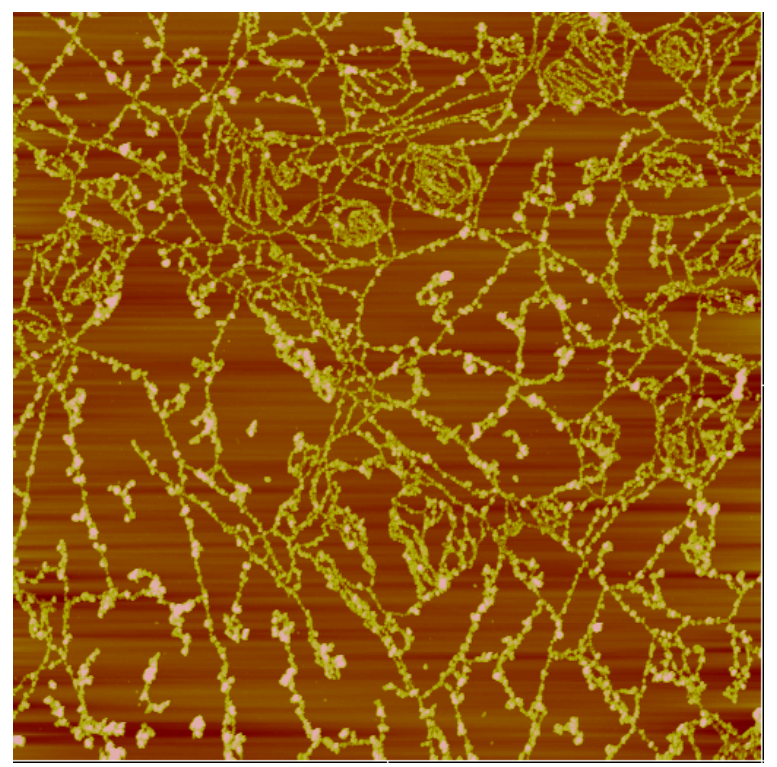

Figure S-1. Randomly distributed Pd nanowires by metallization of freely deposited DNA melecules. Scan area: $5 \times 5 \mathrm{~m}^{2}$; high scale: $60 \mathrm{~nm}$.

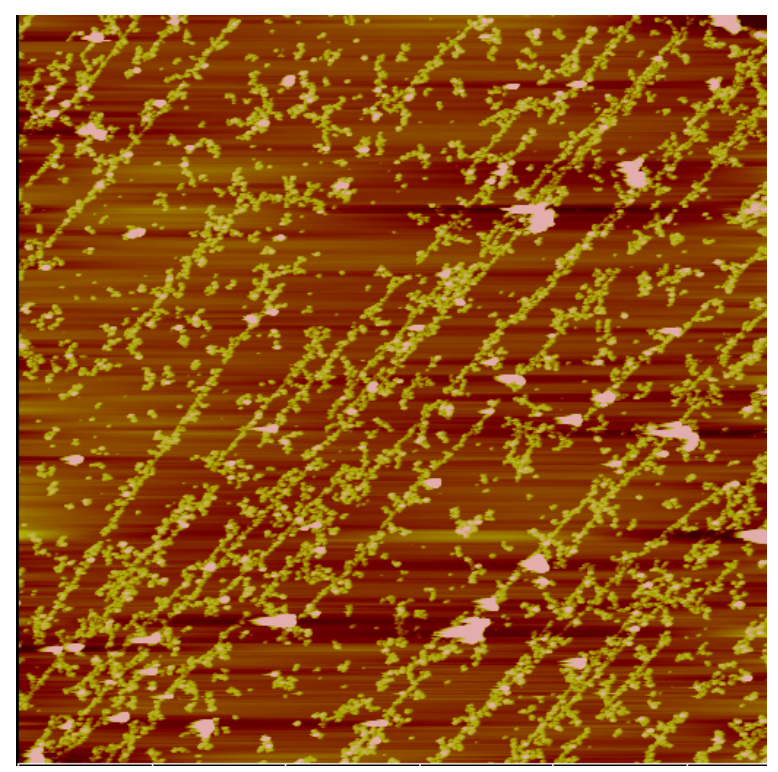

Figure S-2. Parallel DNA molecules metallized on "wet" surface showing branches along the metallic wires due to random metal deposition happened in solution. Scan area: $14 \times 14 \mu \mathrm{m}^{2}$; high scale: $50 \mathrm{~nm}$. 


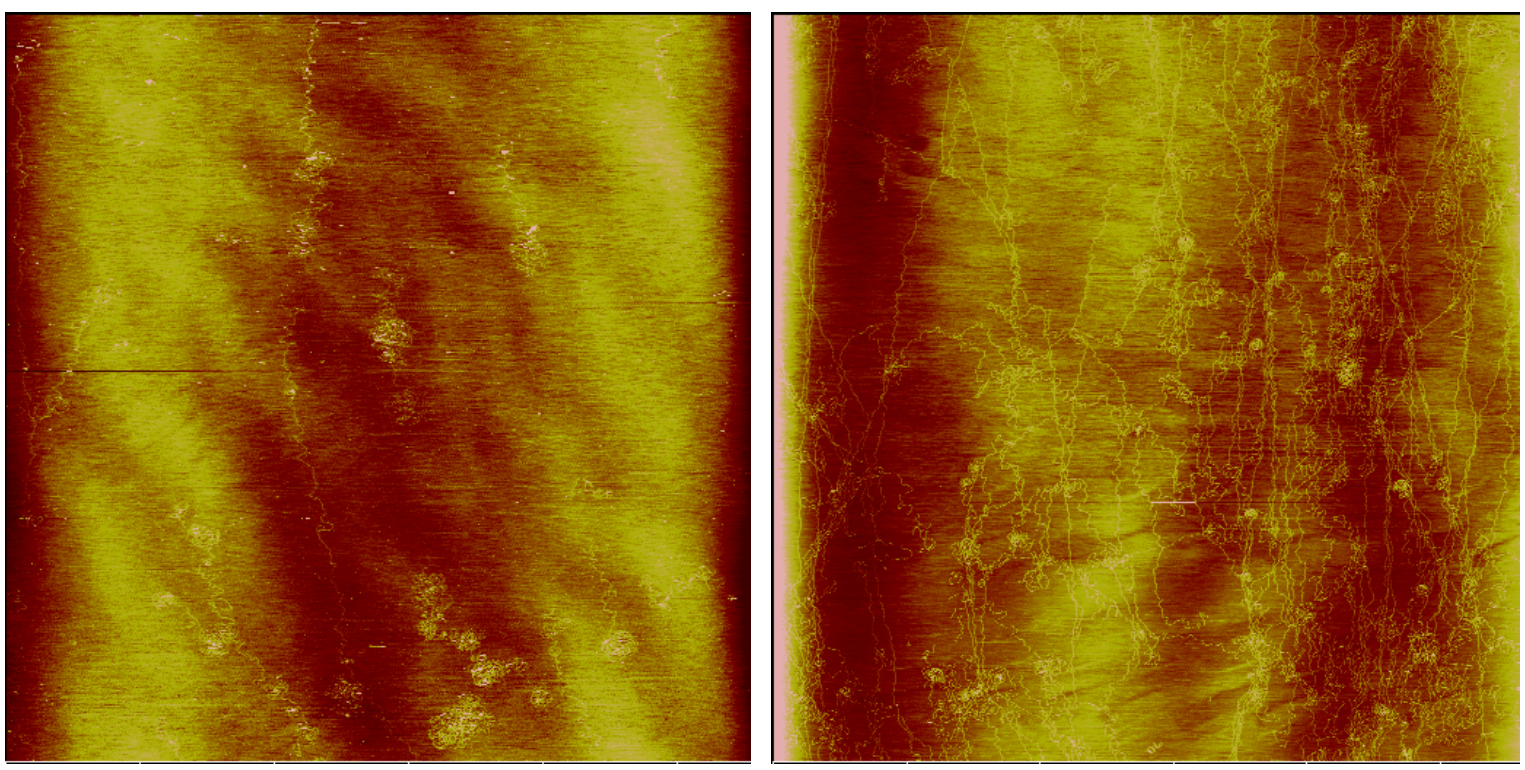

Figure S-3. DNA molecules combed at high $\mathrm{Mg}^{2+}$ concentrations $(1 \mathrm{mM})$. DNA concentrations are 5 $\mu \mathrm{g} / \mathrm{mL}$ (left) and $10 \mu \mathrm{g} / \mathrm{mL}$ (right) correspondingly. The results show DNA cannot be well-combed due to too strong surface adhesion (surface friction) that does not favor the movement of DNA chains essential for alignment. 